\title{
Evaluation of Antidiarrhoeal Potential of Ailanthus Excelsa (Roxb) Bark Extract in Rats
}

\author{
Naresh Kumar ${ }^{1}$ Surendra Kr. Sharma ${ }^{2}$ \\ Pharmacognosy Discipline, Faculty of Pharmacy \\ Guru Jambheshwar University of Science and Technology, Hisar
}

\begin{abstract}
The chloroform, aqueous and ethanolic extract of bark of Ailanthus excelsa was studied for its antidiarrhoeal properties in experimental diarrhoea, induced by castor oil and Effect on normal defecation in rats, at the doses of 100, 200 and $400 \mathrm{mg} / \mathrm{kg}$ per orally. The ethanolic extract showed significant and dose-dependent antidiarrhoeal activity in both models, when compared to standard atropine sulphate $(5 \mathrm{mg} / \mathrm{kg}$; i.m. $)$. The results showed that the ethanolic extract of bark of Ailanthus excelsa have a significant antidiarrhoeal activity and supports its traditional uses.
\end{abstract}

Keywords: Ailanthus excelsa, Simaroubaceae, Antidiarrhoeal activity.

\section{INTRODUCTION}

In developing countries, a quarter of infant and child hood mortility is related to diarrhea ${ }^{1}$. The highest mortality rates have been reported in children less than 5 year of age. During the past decade, oral dehydration therapy has reduced mortality rate of acute diarrhoeal disease, where chronic diarrhea remains a life threatening problem in those regions where malnutrition is a common co-existing complicated factor. The other factors are also affected, such as infective, immunological and nutritional position of the region has been responsible for diarrhoeal syndrome $^{2}$. In India many plants available and conveniently used in traditional folklore medicines for treatment of diarrhea and dysentery ${ }^{3}$. Ailanthus excelsa (Roxb) syn Pongelion wightii Tiegh (Simaroubaceae) is a lofty deciduous tree, commonly called "Tree of Heaven". It is found widely throughout India. It cultivated in road side and garden. It is propagated by seed ${ }^{4}$. The bark of plant is used traditionally as anthelmintic, febrifuge, expectorant and antiseptic. It is also used in treatment of asthma, bronchitis, diarrhea and dysentery ${ }^{5,6}$. In local region of Mumbai, the bark and leaves are used as tonic and espially used in debility after child birth.

A decoction of leaves is used for washing of wounds, swelling and skin eruption. An alcoholic extract of leaf and stem bark exhibited remarkably high anti-implantation and early abortificient activity in female albino rats ${ }^{7,8}$. In present study we have evaluated antidiarrhoeal potential of Ailanthus excelsa (Roxb) bark extract using castor oil induced diarrhea in albino wistar rats and effect on normal defecation in rats, since there is no scientific proof justifying the traditional used of plant for the treatment of diarrhea.

\section{Material AND MethodS}

\subsection{Plant Material}

The bark of Ailanthus excelsa were collected during the month of June 2005 from road side at village Bhathera, Distt. Rewari (Haryana), North India. The plant material was taxonomically identified and authenticated by Dr H.B. Singh, Head Raw Material Herbarium \& Museum, Ref. No. NISCAIR/RHM/F-3/2005/Consult-590/70. A voucher specimen has been submitted in Department of Pharmaceutical Science, Guru Jambheshwar University of Science \& Technology Hisar. The plant material was air-dried at room temperature and then powdered. All other chemicals used were of analytical reagent grade.

\subsection{Preparation of Extract}

The dried powder ( $3 \mathrm{~kg}$ ) of bark of Ailantus excelsa was exhausted successively by pet ether, chloroform and ethanol $(95 \%)$ by hot extraction process and then aqueous extract was prepared by maceration in distilled water for $18 \mathrm{hrs}$. The liquid extract so obtained was concentrated in vacuum at $40^{\circ} \mathrm{C}$. These extracts were stored in refrigerator at $4^{\circ} \mathrm{C}$ until used for experiment reported in this study. 


\subsection{Animals}

The either sex of albino wistar rats (170-210 g) were used for the study. They were fed with standard diet and Water ad libitum. The animals were housed in standard cages and acclimatized for a period of 14 days. The approval for the study was obtained from the Animal Ethics Committee, Guru Jambheshwar University of Science \& Technology Hisar.

\subsection{Castor Oil Induced Diarrhea}

The method reported by Awouters et al ${ }^{9,10}$ with modification has been used in present study. Rats of either sex were fasted for $18 \mathrm{hr}$. They were then dividing into five groups of six animals in each group. Then extracts were administered orally at doses of 100,200 and $400 \mathrm{mg} / \mathrm{kg}$ by gavage as suspension to the first three groups of animals. The fourth groups receive atropine $(0.1 \mathrm{mg} / \mathrm{kg}$ i.p). The fifth groups serve as blank, was administered with $1 \% \mathrm{w} / \mathrm{v}$ aqueous suspension $(5 \mathrm{ml} / \mathrm{kg}$ ) after 60 minutes of treatment, the animal of each groups receive $1 \mathrm{ml}$ of castor oil orally by gavage and consistency of fecal material and frequency of defecation was noted up to 4 hours in transparent plastic dishes place beneath the individual rats cages.

\subsection{Effect on Normal Defecation In Rats}

The wistar albino rats were divided into four groups of six animals in each group. They were placed in individually in polypropylene cages with plastic dishes beneath each cage. The ethanol, chloroform and aqueous extract at doses of 100,200 and $400 \mathrm{mg} / \mathrm{kg}$ were given orally to the first three groups. While one groups served as a negative control and receive a $1 \% \mathrm{w} / \mathrm{v}$ aqueous carboxy methyl cellulose suspension $(5 \mathrm{mg} / \mathrm{kg})$. The number of feces in each group was counted every four hours. The percentage reduction in the number of feces in the treated groups was compared with that of the control animals for each hour.

$$
\% \text { Inhibition }=\frac{\text { Control mean }- \text { Treated mean }}{\text { Control mean }} \times 100
$$

\section{RESULTS}

Table1. Effect of chloroform extract of A. excelsa on castor oil induced diarrhea in rats

\begin{tabular}{|l|l|l|l|}
\hline Treatment & Dose & $\begin{array}{l}\text { Mean no. of defecations in } \\
4 \mathrm{hr}\end{array}$ & $\%$ inhibition \\
\hline $\begin{array}{l}1 \% \mathrm{w} / \mathrm{v} \mathrm{aqueous} \mathrm{carboxy} \\
\text { methylcellulose suspension }\end{array}$ & $5 \mathrm{mg} / \mathrm{kg}$ & $9 \pm 0.7304$ & - \\
\hline Atropine (Standard) & $0.1 \mathrm{mg} / \mathrm{kg}$ & $3 \pm 0.3652$ & $66.6 \%^{* *}$ \\
\hline $\begin{array}{l}\text { Chloroform extract of } A . \\
\text { excelsa }\end{array}$ & $100 \mathrm{mg} / \mathrm{kg}$ & $7 \pm 0.5774$ & $22.2 \%^{*}$ \\
\hline & $200 \mathrm{mg} / \mathrm{kg}$ & $5 \pm 0.3554$ & $44.4 \%^{*}$ \\
\hline & $400 \mathrm{mg} / \mathrm{kg}$ & $4 \pm 0.5166$ & $55.5 \%^{* *}$ \\
\hline
\end{tabular}

$* * P<0.05, * P<0.001$, when compared with controls (Dunnett's $t$-test after analysis of variance). Result are mean $\pm \operatorname{SEM}(N=6)$.

Table2. Effect of aqueous extract of A.excelsa on castor oil induced diarrhea in rats

\begin{tabular}{|l|l|l|l|}
\hline Treatment & Dose & $\begin{array}{l}\text { Mean no. of defecations in } \\
4 \mathrm{hr}\end{array}$ & $\%$ inhibition \\
\hline $\begin{array}{l}1 \% \text { w/v aqueous carboxy } \\
\text { methylcellulose suspension }\end{array}$ & $5 \mathrm{mg} / \mathrm{kg}$ & $9 \pm 0.7304$ & - \\
\hline Atropine (Standard) & $0.1 \mathrm{mg} / \mathrm{kg}$ & $3 \pm 0.3652$ & $66.6 \%^{* *}$ \\
\hline Aqueous extract of A. excelsa & $100 \mathrm{mg} / \mathrm{kg}$ & $8 \pm 0.3652$ & $11.1 \%^{*}$ \\
\hline & $200 \mathrm{mg} / \mathrm{kg}$ & $6 \pm 0.6325$ & $33.3 \%^{*}$ \\
\hline & $400 \mathrm{mg} / \mathrm{kg}$ & $5 \pm 0.4473$ & $44.4 \%^{*}$ \\
\hline
\end{tabular}

${ }^{* *} P<0.05,{ }^{*} P<0.001$, when compared with controls (Dunnett's $t$-test after analysis of variance). Result are mean $\pm \operatorname{SEM}(N=6)$. 
American Research Journal of Pharmacy, Volume 1, Issue 1, 2015

ISSN 2380-5706

Table3. Effect of ethanol extract of A.excelsa on castor oil induced diarrhea in rats

\begin{tabular}{|l|l|l|l|}
\hline Treatment & Dose & $\begin{array}{l}\text { Mean no. of defecations in } \\
4 \mathrm{hr}\end{array}$ & $\%$ inhibition \\
\hline $\begin{array}{l}1 \% \text { w/v aqueous carboxy } \\
\text { methylcellulose } \\
\text { suspension }\end{array}$ & $5 \mathrm{mg} / \mathrm{kg}$ & $9 \pm 0.7304$ & - \\
\hline Atropine (Standard) & $0.1 \mathrm{mg} / \mathrm{kg}$ & $3 \pm 0.3652$ & $66.6 \%^{* *}$ \\
\hline $\begin{array}{l}\text { Ethanol extract of } A . \\
\text { excelsa }\end{array}$ & $100 \mathrm{mg} / \mathrm{kg}$ & $7 \pm 0.6832$ & $22.2 \%^{*}$ \\
\hline & $200 \mathrm{mg} / \mathrm{kg}$ & $5 \pm 0.5774$ & $33.3 \%^{*}$ \\
\hline & $400 \mathrm{mg} / \mathrm{kg}$ & $4 \pm 0.5165$ & $55.5 \%^{* *}$ \\
\hline
\end{tabular}

$* * P<0.05, * P<0.001$, when compared with controls (Dunnett's $t$-test after analysis of variance). Result are mean $\pm \operatorname{SEM}(N=6)$.

Table4. Effect of chlroform extract of A.excelsa by Effect on normal defecation in rats

\begin{tabular}{|l|l|l|l|}
\hline Treatment & Dose & $\begin{array}{l}\text { Mean no. of defecations in } \\
4 \mathrm{hr}\end{array}$ & \% inhibition \\
\hline $\begin{array}{l}1 \% \text { w/v aqueous carboxy } \\
\text { methylcellulose } \\
\text { suspension }\end{array}$ & $5 \mathrm{mg} / \mathrm{kg}$ & $6 \pm 0.258$ & - \\
\hline $\begin{array}{l}\text { Chloroform extract of } A . \\
\text { excelsa }\end{array}$ & $100 \mathrm{mg} / \mathrm{kg}$ & $5 \pm 0.0 .365$ & $16.6 \%^{*}$ \\
\hline & $200 \mathrm{mg} / \mathrm{kg}$ & $3 \pm 0.365$ & $50.0 \%^{*}$ \\
\hline & $400 \mathrm{mg} / \mathrm{kg}$ & $2.3 \pm 0.516$ & $55.5 \%^{* *}$ \\
\hline
\end{tabular}

** $P<0.05, * P<0.001$, when compared with controls (Dunnett's $t$-test after analysis of variance). Result are mean $\pm \operatorname{SEM}(N=6)$.

Table5. Effect of aqueous extract of A.excelsa by Effect on normal defecation in rats

\begin{tabular}{|l|l|l|l|}
\hline Treatment & Dose & $\begin{array}{l}\text { Mean no. of defecations in } \\
4 \mathrm{hr}\end{array}$ & $\%$ inhibition \\
\hline $\begin{array}{l}1 \% \quad \mathrm{w} / \mathrm{v} \mathrm{aqueous} \\
\text { carboxy methylcellulose } \\
\text { suspension }\end{array}$ & $5 \mathrm{mg} / \mathrm{kg}$ & $6 \pm 0.258$ & - \\
\hline $\begin{array}{l}\text { Aqueous extract of } A . \\
\text { excelsa }\end{array}$ & $100 \mathrm{mg} / \mathrm{kg}$ & $5.1 \pm 0.307$ & $13.5 \%^{*}$ \\
\hline & $200 \mathrm{mg} / \mathrm{kg}$ & $3.6 \pm 0.336$ & $38.8 \% *$ \\
\hline & $400 \mathrm{mg} / \mathrm{kg}$ & $3.2 \pm 0.494$ & $44.4 \% * *$ \\
\hline
\end{tabular}

** $P<0.05, * P<0.001$, when compared with controls (Dunnett's $t$-test after analysis of variance). Result are mean $\pm \operatorname{SEM}(N=6)$.

Table6. Effect of ethanol extract of A.excelsa by Effect on normal defecation in rats

\begin{tabular}{|l|l|l|l|}
\hline Treatment & Dose & $\begin{array}{l}\text { Mean no. of defecations in } \\
4 \mathrm{hr}\end{array}$ & $\%$ inhibition \\
\hline $\begin{array}{l}1 \% \text { w/v aqueous } \\
\text { carboxy methylcellulose } \\
\text { suspension }\end{array}$ & $5 \mathrm{mg} / \mathrm{kg}$ & $6 \pm 0.258$ & - \\
\hline $\begin{array}{l}\text { Ethanol extract of A. } \\
\text { excelsa }\end{array}$ & $100 \mathrm{mg} / \mathrm{kg}$ & $5.0 \pm 0.258$ & $16.5 \%^{*}$ \\
\hline & $200 \mathrm{mg} / \mathrm{kg}$ & $2.8 \pm 0.344$ & $52.6 \% \%^{* *}$ \\
\hline & $400 \mathrm{mg} / \mathrm{kg}$ & $2.0 \pm 0.365$ & $66.4 \%^{* *}$ \\
\hline
\end{tabular}

${ }^{* *} P<0.05,{ }^{*} P<0.001$, when compared with controls (Dunnett's $t$-test after analysis of variance). Result are mean $\pm \operatorname{SEM}(N=6)$. 


\section{DISCUSSION}

The ethanolic extract of the A.excelsa exhibit a potential antidiarrheal action when studied by using two animal models. These models are very effective for the investigation of the antidiarrhoeal activity of plant which used traditionally for the treatment of the diarrhea. Our investigation of the scientific reason behind folklore use of A.excelsa in the treatment of diarrhea dieases by which patient may be died. In this investigation the ethanolic extract of A.excelsa bark show potential antidirrhoael potential is dose dependant.

\section{ACKNOWLEDGEMENTS}

The authors wish to thank Animal ethical committee of University, for providing animal to complete my research work.

\section{REFERENCES}

[1] Jousilathi P., Madkour SM., Lambrechts T., Sherwine E., Diarrheal morbidity and home treatment practices in Egypt. Public Health 1977, 111; 5-10.

[2] Galvez J., Sanchez MF., Jimenez Jj., effect of quercitrin on lactose induced chronic diarrhea in rats. Planta Med 1995, 61; $302-306$.

[3] Chopra RN., Nayer SL., Chopra IC., Glpssary of Indian medicinal plants. Council of Scientific and Industrial Research, New Delhi. 1956.

[4] Sharma R., Medicinal plants of India (An Encyclopaedia). 2003, 15-16.

[5] Anonymous, Wealth of India, PID (CSIR). 1985, 116-118.

[6] Basu BD., Kirtikar KR., Indian medicinal plant.1956, $2^{\text {nd }}$ ed; 503-507.

[7] Singh VK., Khan M A., Medicinal plants and Folklortes. 1990, 149-155.

[8] Dhanasekran S., Suresh B., Sethuramanm., Rajan S., Indian J Exp. Bio. 1993, 31 (4); 384-385.

[9] Awouters F., Nimegeers CJE; Lenaerts FM., Delay of castor oil diarrhea in rats; A new way to evaluate inhibitors of prostaglandin biosynthesis. Indian J Pharmacol. 1978, 30 , 41-45.

[10] Perianayagam JB., Sharma SK., Pillai K., evaluation of antidiarrhoeal potential of Trichodesma indicum root extract in rats. Methods Find. Exp. Clin. Pharmacol. 2005, 27 (7), 1-5. 